\title{
Using IMS Learning Design to Model Curricula
}

\author{
Citation for published version (APA):
}

Tattersall, C., Janssen, J., Van den Berg, B., Hummel, H., \& Koper, R. (2006). Using IMS Learning Design to Model Curricula. Interactive LearnIng Environments, 15(2), 181-189.

https://doi.org/10.1080/10494820701360631

DOI:

$10.1080 / 10494820701360631$

Document status and date:

Published: 05/09/2006

Document Version:

Peer reviewed version

Document license:

CC BY-NC-ND

Please check the document version of this publication:

- A submitted manuscript is the version of the article upon submission and before peer-review. There can be important differences between the submitted version and the official published version of record. People interested in the research are advised to contact the author for the final version of the publication, or visit the DOI to the publisher's website.

- The final author version and the galley proof are versions of the publication after peer review.

- The final published version features the final layout of the paper including the volume, issue and page numbers.

Link to publication

\section{General rights}

Copyright and moral rights for the publications made accessible in the public portal are retained by the authors and/or other copyright owners and it is a condition of accessing publications that users recognise and abide by the legal requirements associated with these rights.

- Users may download and print one copy of any publication from the public portal for the purpose of private study or research.

- You may not further distribute the material or use it for any profit-making activity or commercial gain

- You may freely distribute the URL identifying the publication in the public portal.

If the publication is distributed under the terms of Article $25 f a$ of the Dutch Copyright Act, indicated by the "Taverne" license above, please follow below link for the End User Agreement:

https://www.ou.nl/taverne-agreement

Take down policy

If you believe that this document breaches copyright please contact us at:

pure-support@ou.nl

providing details and we will investigate your claim.

Downloaded from https://research.ou.nl/ on date: 26 Apr. 2023 


\title{
Using IMS Learning Design to Model Curricula
}

\author{
Colin Tattersall*, José Janssen, Bert van den Berg, Hans Hummel, Rob Koper \\ The Open University of the Netherlands, the Netherlands
}

\begin{abstract}
The traditional notion of the curriculum as a fixed list of topics to be studied sequentially is under strain as pressure for flexibility in education increases. However, curriculum flexibility can lead to curriculum complexity, so that guidance systems are needed to assist learners in their study choices. This article proposes the use of the open, technical specification IMS Learning Design as a formal model for the description of curricula used by guidance support systems for learners. The article compares the approach to other work in the area, and illustrates its application with a number of case studies. The article concludes by describing the type of advanced guidance services which are enabled through a standardised approach and examining the elearning infrastructure required when implementing the approach.
\end{abstract}

Keywords: Guidance, Lifelong Learning, Curriculum design, Standardisation.

\section{Introduction}

A standards-based IT infrastructure is now in place in educational institutions around the world, opening the doors to mainstream, large-scale, web-based education (Brusilovsky \& Vassileva, 2003) and offering the possibility of increased curriculum flexibility (Schellekens, Paas, \& Van Merriënboer, 2003). Traditionally, educational systems have shown a rigid character, with learners being grouped into cohorts for fixed-length programmes with pre-determined start dates and pre-determined structures (Clark \& Shatkin, 2003;

Kirkpatrick \& McLaughlan, 2000). In contrast, flexible systems are designed to allow learners "to follow open learning pathways of their own choice, rather than being obliged to follow predetermined routes to specific destinations” (CEC, 2000, p. 8). Jongbloed suggests that lifelong learning will require universities to develop mass-individualisation capabilities, so that educational offerings can be picked-and-mixed to match the specific needs of individuals (Jongbloed, 2002).

Credit and modularisation play a central role in achieving this freedom (Hart \& Howieson, 2004; Moon, 1988). Modular educational systems revolve around units which can be combined (i.e. sequenced) by learners to reach educational goals. However, the flipside of modularisation is complexity. Yorke highlights that "as the unitization of curricula spreads through higher education, so there is a need for greater guidance for students to navigate their way through the schemes” (Yorke, 1999, p. 105). This point is also raised by Gledhill who notes the complexity inherent in modular programmes and the difficulties this implies for advice-giving (Gledhill, 1999).

Broadening the scope from a specific institution to cover multiple providers in an international context reveals the true complexity facing lifelong learners - Barnett notes 100 university institutions and 40,000 courses in the UK alone (Barnett, 2000), and an indication of the European scale can be gained through the thousands of learning opportunities accessible through the PLOTEUS portal (PLOTEUS, 2006).

* $\quad$ Corresponding author. Postal Address: The Open University of the Netherlands, Valkenburgerweg 1776419 AT Heerlen, the Netherlands; Email: colin.tattersall@ou.nl 
As a result of this complexity, guidance for European learners has been identified as having an essential role to play in assisting them to develop effective self-management of their learning and career paths (CEC, 2004a). Guidance systems must be designed to help learners gauge and review their current and desired competences, and plan progression in an international context and over long periods of time. This article's underlying thesis is that to avoid fragmented and unsustainable development of guidance systems, an open, standardised language for modelling curricula should be used. We first identify the requirements for such a language, before reviewing candidate approaches.

\section{Curriculum Modelling Requirements}

Requirements for the modelling of curricula can be found in the curriculum design literature (Bell \& Wade, 1993; Ertl, 2002; Glatthorn , Floyd Boschee, \& Whitehead, 2005; Van den Akker, 2003), lifelong learning policy documents (NOCN, 2004a; SCQF, 2003) and literature on credit accumulation and transfer (Adam, 2001; Gosling, 2001; Winter, 1994). We summarise the requirements in the following points:

1. Modular composition: Curricula must be able to be constructed from units.

2. Nested composition: Curricula must be able to be composed of other curricula.

3. Selection: It must be possible to specify which elements of a curriculum are mandatory and which are optional.

4. Sequencing: it must be possible to specify constraints on the order in which elements of a curriculum are to be completed.

5. Completion: The requirements for completion of a curriculum element, and of the curriculum itself, must be able to be specified.

6. Conditional Composition: It must be possible to specify conditions under which curriculum elements are to be included or excluded.

Furthermore, drawing on the educational modelling approach used in (Koper \& Manderveld, 2004), we add the following generic requirements:

7. Formality: the language must describe a curriculum in a formal way, so that automatic processing is possible.

8. Interoperability: The language must support interoperability of curricula so that different support systems can share and exchange information.

\section{Existing approaches to modelling curricula}

There are a number of existing approaches to specifying what needs to be done by learners to achieve educational goals. The European Credit Transfer and Accumulation System or ECTS (CEC, 2004b), is a systematic way of describing the student workload required to achieve the objectives of an educational programme (e.g. 'students must accumulate a total of 60 ECTS credit points'). ECTS is, however, not a formal modelling language and does not provide a means of fully specifying curricula (e.g. there are no constructs to describe sequences and selections using ECTS). The National Open College Network Credit and Qualification Framework's Technical Specification for Qualifications (NOCN, 2004b) does include the notion of Rules of Combination describing mandatory and optional units. However, as yet, no formal modelling language is used for the specification of the rules, limiting the opportunities for automated processing. 
Significant research in curriculum modelling has been carried out over the years in the area of Intelligent Tutoring Systems (Baldoni, Baroglio, \& Patti, 2002; Murray, 1998). While this work has a formal basis which meets the generic educational modelling requirements described above, approaches to curriculum modelling in the ITS worlds have tended to involve the modelling of conceptual domain knowledge (what is related to what in the domain) and the modelling of knowledge pre-requisites (what must be learned before what) so that automatic planning processes can perform curriculum sequencing. We view this as a far deeper and correspondingly more taxing level of modelling than is required for guidance. Moreover, as highlighted by Hübscher , rather than being predefined and fixed, the order in which concepts and skills are learned can vary in different pedagogical approaches (e.g. Problem-Based Learning vs. Programmed Instruction) (Hübscher, 2001).

Work on the eXchanging Course-Related Information (XCRI, 2006) reference model is drawing on a number of other international initiatives, particularly from the Scandinavian countries, to define a vocabulary for describing course-related information encompassing course marketing, course quality assurance, enrolment and reporting requirements. This is interesting work in progress, albeit with a scope which is slightly different to that of the work described in this article, focusing more on institutional publication of course information to diverse audiences rather than the learner guidance problem. However, the XCRI reference model includes some facilities for modelling curricula which we believe could be usefully extended with the constructs included in this article.

Another candidate for a curriculum modelling language is IMS Learning Design (IMSLD, 2003; Koper \& Tattersall, 2005). IMSLD provides constructs allowing instructional designers to specify which roles should carry out which activities, with which supportive learning materials and services in order to achieve learning objectives. Reviewing the match between IMSLD and the requirements identified above, we find:

1. Modular composition

A Unit of Learning (UoL) can reference another UoL within an activity structure through a uniform resource identifier. We note here for completeness that the text of the IMSLD specification contains a technical restriction in the area of inter-UoL referencing but which is not formally enforced in the associated XML schema.

2. Nested composition

Activity structures can be nested, thereby allowing nesting of UoLs.

3. Selection

The type of an activity structure can be indicated as a selection indicating that the elements of the selection may be done in any order. Moreover an attribute can be specified (number-to-select) to indicate how many elements of the activity structure must be completed before the whole activity structure is considered complete (e.g. four of the six specified possibilities, one of the seven etc).

4. Sequencing

The type of an activity structure can be indicated as a sequence indicating that the elements of the selection must be done in the specified order.

5. Completion

IMSLD has an expression language through which complex rules for completion can be defined.

6. Conditional Composition

The expression language can also be used to describe conditions based on various types of properties (of the learner, the curriculum, etc). 


\section{Formality}

IMSLD is described using the XML Schema formalism allowing various types of processing to be brought to bear on information modelled using the specification.

8. Interoperability

IMSLD is an open specification published by a consortium which promotes e-learning interoperability.

\section{Experience using IMSLD to model curricula}

A variety of curricula have been modelled using IMSLD, drawn from three primary sources. First, the distance teaching programmes offered at the Open University of the Netherlands were analysed. Second, an analysis was made of a selection of curricula found via the PLOTEUS service. Finally, a set of learning programmes which can be found on the Internet was analysed. Examples are given below, with the description of the programme being matched with a textual description of its mapping to IMSLD.

- Bachelors degree programme in Dutch Law

o The Bachelor programme in Dutch Law consists of 42 modules and is divided into two phases: the propedeutic phase (14 modules) and the post-propedeutic phase (26 modules). The former begins with an introductory course in Law (which counts for two modules) after which students follow the remaining 12 modules in any order. The modules of the post-propedeutic phase can be followed in any order. The bachelor is completed with a compulsory "integration practical" which counts for 2 modules.

o The UoL representing this curriculum consists of an IMSLD Activity Structure (AS) which is a sequence, containing nested ASs for both the propedeutic and post-propedeutic phases, followed by a UoL representing the practical. The propedeutic phase is a sequence which starts with the UoL for the introductory course and is followed by a nested AS representing the remaining 12 modules (a selection). The post-propedeutic phase AS is a selection of the 26 modules.

- European Computer Driving Licence, e-citizen programme (ECDL, 2006)

o e-Citizen is the new end-user computer skills certification programme from the European Computer Driving Licence (ECDL) Foundation. The programme is designed to cater for those with a limited knowledge of computers and the Internet but who wish to gain valuable everyday computer and Internet skills. The e-Citizen Syllabus has been defined by the ECDL Foundation in three blocks which are followed in progression: Block 1: Foundation Skills, Block 2: Information Search and Block 3: E-Participation. Each block consists of a number of topics (e.g. The Computer, Files and Folders).

- A UoL is defined for each topic and grouped into an AS per block (selection). These three ASs are included in a sequence AS, ordering the blocks in the correct sequence.

- University of Washington Certificate Program in Aircraft Composite Materials and Manufacturing (UoW, 2006)

o This online learning programme targets employed engineers and others who cannot take courses on campus. Coursework must be completed in order, beginning with Aircraft Composite Materials, followed by Aircraft Composite Manufacturing. Thereafter, learners choose one of two elective courses: Aircraft Composite Tooling or Aircraft Composite Repair.

o This certificate programme is modelled with an AS of type sequence, which orders the first two modules, followed by a nested AS of type selection (number-to-select=1) containing UoLs representing the two elective modules. 
- UK National Vocational Qualification for Registered Manager (Edexcel, 2006)

o The qualification is intended for managers, assistant managers and others who have managerial responsibilities within regulated care services. All four mandatory units, one unit from each of the four optional groups and two units from any of the optional groups are required for successful completion of this NVQ.

o Although seemingly comparable with the examples described above, this curriculum requires a higher degree of sophistication of IMSLD modelling. The mandatory units are dealt with using an AS of type selection. Learners' constrained picking and mixing from the four optional groups is handled using conditions. An AS containing all 16 optional modules is defined, together with a number of conditions. The conditions track whether one UoL from each group has been completed and whether 2 additional UoLs have been completed.

- B.A. in Computer Science - Systems \& Applications Computer Science (OUI, 2006)

o Students must accumulate 29 credits from the required modules and 14 credits from the elective modules. Those who have already taken Formal Automata Theory may not take Automata Theory and Formal Languages and must therefore accumulate 31 credits from required courses and 12 credits in electives in Computer Science.

o The heart of this curriculum is straightforward to model using activity structures. IMSLD conditions are, however, required first to track the ongoing accumulation of credit points (since course completion depends on a credit total rather than on a number of completed modules), as well as to adjust the total needed from the required modules depending on information on the learner's course history, excluding the relevant course (in IMSLD terms, using HIDE) appropriately.

\section{Discussion}

IMSLD's ability to sequence, select and nest various combinations of units of learning, together with its condition language provide a suitable base from which to tackle a variety of curriculum modelling issues. Although many approaches, languages and formalisms exist in which curricula could be specified (e.g. word processing documents, Java programs, HTML), IMSLD’s nature as an open specification, published by a nonprofit organisation committed to its maintenance and with a growing set of development tools, make it an attractive solution to the curriculum modelling problem; using it avoids the need to develop a new language to underpin learner guidance support systems.

We note here that in addition to the curriculum structuring concepts covered by IMSLD, further informative information is required to fully describe learning opportunities. Information on the awarding institution, mode (and language) of study, access requirements and workload can be used to help learners make informed choices on their learning paths. The XCRI initiative (Stubbs \& Wilson, 2006) is making strong headway in promoting interoperability in this area.

With standardised course and curriculum data in place, a variety of guidance systems and services can be created focusing on added value to the learner rather than the specifics of a given provider's data. The sophistication of this guidance can range from straightforward registration of the learner's progression and reviewing of course requirements to the independent brokering envisaged in the CUBER project (Boursas, Keller, \& Magerkurth, 2003). In addition, once definitional data is combined with data on actual learner progression through curricula, a host of new possibilities are opened (Barré, Choquet, Corbière, \& Iksal, 2004; Rasseneur, Jacoboni, \& Tchounikine, 2004; Tattersall et al., 2005). These include advice on the most efficient path through a flexible curriculum (to support the 'calculating learner'), the path of highest quality 
(when learners want to get the best results from their learning efforts), or the path along which other peers are available for collaborative study.

Furthermore, a move from impersonal progression data (i.e. learner ' $n$ ' has completed course ' $x$ ') to data tagged with the specifics of individuals such as age, sex, educational background, marital status, geographical location, current job and so on, paves the way for recommendations from highly specific perspectives ("others with an interest in ornithology have tended to now study course x", "several alumni from your bachelor degree programme have followed course y", "friends of your friends are showing interest in a course on topic z”).

Clearly the use of IMSLD as a curriculum modelling language requires other aspects of an integrated elearning system (Koper, 2003) to be in place:

- E-learning modules which are addressable as UoLs and able to be referenced from other UoLs.

- Learner record systems, or e-portfolios, so that conditions can be defined in terms of their content;

- Infrastructure to record in the above systems that a UoL has been completed, propagating this fact to associated systems;

- A curriculum processing engine, which, given a curriculum modelled using IMSLD and information on the learner, is able to compute what remains to be done by the learner to reach his or her educational goal.

Although significant work remains to be done, the use of open, technical specifications and standards holds the promise of a sustainable approach to the development of integrated e-learning systems.

\section{Acknowledgement}

The work on this paper has been partly sponsored by the TENCompetence Integrated Project that is funded by the European Commission's 6th Framework Programme, priority IST/Technology Enhanced Learning. Contract 027087 (www.tencompetence.org)

\section{Notes on Contributors}

All authors work at the Educational Technology Expertise Centre of the Open University of the Netherlands.

Colin Tattersall is Associate Professor, with research interests in the areas of standardisation and innovation in e-learning.

José Janssen is Assistant Professor, investigating learning paths and navigation in distributed learning networks and competence development programmes.

Bert van den Berg is Assistant Professor, focusing on simulation of learner paths in learning networks.

Hans Hummel is Associate Professor, researching critical facilities for lifelong learning networks. His main interests focus on adaptive way finding and competence development programmes. 
Rob Koper is a full Professor in educational technology and director of the technology development programme the Open University of the Netherlands. His research focuses on self-organised distributed learning networks for lifelong learning.

\section{References}

Adam, S. (2001). A Pan-European credit accumulation framework - dream or disaster? Higher Education Quarterly, 55(3), 292-305.

Baldoni, M., Baroglio, C., \& Patti, V. (2002). Supporting Users in Adaptive Web-based Applications: Techniques from Reasoning about Actions. Paper presented at the WOA 2002, Milan, Italy,.

Barnett, R. (2000). Supercomplexity and the curriculum. Studies in Higher Education, 25(3), 255-265.

Barré, V., Choquet, C., Corbière, A., \& Iksal, S. (2004). Usage Analysis in an e-Learning System: LD Representation Significance. Paper presented at the ICALT 2004, Joensuu, Finland.

Bell, G. H., \& Wade, W. (1993). Modular Course Design in Britain: Some Problems, Issues and Opportunities. Journal of Further and Higher Education, 17(1), 3-12.

Boursas, L., Keller, J., \& Magerkurth, S. (2003). A Web-Based Decision Support System for Course Alternatives in the Study Programme Broker CUBER. Paper presented at the ED-MEDIA 2003 World Conference on Educational Multimedia, Hypermedia \& Telecommunications, Honolulu, Hawaii.

Brusilovsky, P., \& Vassileva, J. (2003). Course sequencing techniques for large-scale web-based education. International Journal of Continuing Engineering Education and Lifelong Learning, 13(1/2), 75-94.

CEC. (2000). A Memorandum on Lifelong Learning. Retrieved February 24th, 2004, from http://europa.eu.int/comm/education/policies/lll/life/memoen.pdf

CEC. (2004a). Draft Resolution on Strengthening Policies, Systems and Practices in the field of Guidance throughout life in Europe (No. 9286/04). Brussels.

CEC. (2004b). ECTS Users' Guide: European Credit Transfer And Accumulation System And The Diploma Supplement. Retrieved September 29th, 2004, from http://europa.eu.int/comm/education/programmes/socrates/ects/guide_en.pdf

Clark, P. G., \& Shatkin, L. (2003). A New Challenge for Education: Addressing the Needs of Lifelong Learners. The Technology Source.

ECDL. (2006). e-Citizen Syllabus Version 1.0. from http://www.ecitizen.co.uk/syllabusguide.pdf

Edexcel. (2006). National Vocational Qualifications in Registered Manager (Adults) at level 4. Retrieved January 19th, 2006, from

http://hsc.edexcel.org.uk/VirtualContent/89598/NVQ_L4_RegisteredManagers_Adult_leaflet.pdf

Ertl, H. (2002). The Concept of Modularisation in Vocational Education and Training: the debate in Germany and its implications. Oxford Review of Education, 28(1), 53-73.

Glatthorn , A. A., Floyd Boschee, F., \& Whitehead, B. M. (2005). The Nature of Curriculum: Sage Publications, Inc.

Gledhill, J. M. (1999). Managing Students. Buckingham: Open University Press.

Gosling, D. (2001). Lost Opportunity: What a Credit Framework Would Have Added to the National Qualification Frameworks. Higher Education Quarterly, 55(3), 270-284.

Hart, J., \& Howieson, C. (2004). Unitisation - Benefits and Issues. Glasgow: Scottish Qualifications Authority.

Hübscher, R. (2001). What's in a Prerequisite. Paper presented at the Second IEEE International Conference on Advanced Learning Technologies (ICALT'01).

IMSLD. (2003). IMS Learning Design Specification. Version 1. Retrieved February 27th, 2004, from http://www.imsglobal.org/learningdesign/index.cfm 
Jongbloed, B. (2002). Lifelong learning: Implications for institutions. Higher Education, 44, 413-431.

Kirkpatrick, D., \& McLaughlan, R. (2000). Flexible Lifelong Learning in Professional Education. Education and Information Technologies, 3(1), 24-31.

Koper, R. (2003). Learning technologies: an integrated domain model. In W. Jochems, J. v. Merriënboer \& R. Koper (Eds.), Integrated eLearning (pp. 64-79). London: RoutledgeFalmer.

Koper, R., \& Manderveld, J. (2004). Educational modelling language: modelling reusable, interoperable, rich and personalised units of learning. British Journal of Educational Technology, 35(5), 537-551.

Koper, R., \& Tattersall, C. (2005). Learning Design: A Handbook on Modelling and Delivering Networked Education and Training (Vol. Heidelberg): Springer Verlag.

Moon, B. (1988). Modular Curriculum. London: Paul Chapman Publishing Ltd.

Murray, T. (1998). A Model for Distributed Curriculum on the World Wide Web. Journal of Interactive Media in Education, 5.

NOCN. (2004a). NOCN Credit and Qualification Framework Technical Specification - General. Retrieved October 3rd, 2005, from http://www.nocn.org.uk/quals/qual-docs/NOCN\%20CQF\%20\%20Technical\%20Specification\%20-\%20General\%20-\%20V2.pdf

NOCN. (2004b). NOCN Credit and Qualification Framework Technical Specification - Qualifications. Derby: National Open College Network.

OUI. (2006). Requirements for interdisciplinary degrees: B.A. in Education (Curriculum \& Instruction Studies) and Computer Science - Systems \& Applications. Retrieved January 19th, 2006, from http://www-e.openu.ac.il/program_of_study/28.htm

PLOTEUS. (2006). Portal on Learning Opportunities throughout the European Space. Retrieved January 19th, 2006, from http://europa.eu.int/ploteus

Rasseneur, D., Jacoboni, P., \& Tchounikine, P. (2004). Using and Enhancing a Normalized IMS-LD Description to Support Learners in their Appropriation of a Distance-Learning Curriculum. Paper presented at the IEEE International Conference on Advanced Learning Technologies (ICALT'2004), Joensuu, Finland.

Schellekens, A., Paas, F., \& Van Merriënboer, J. J. G. (2003). Flexibility in higher professional education: A survey in business administration programmes in the Netherlands. Higher Education, 45, 281-305.

SCQF. (2003). An Introduction to the Scottish Credit and Qualifications Framework, 2nd Edition.

Stubbs, M., \& Wilson, S. (2006, March 30th-31st). eXchanging Course-Related Information: a UK serviceoriented approach. Paper presented at the International Workshop in Learning Networks for Lifelong Competence Development, TENCompetence Conference, Sofia, Bulgaria.

Tattersall, C., Manderveld, J., Van den Berg, B., Van Es, R., Janssen, J., \& Koper, R. (2005). Self Organising Wayfinding Support for Lifelong Learners. Education and Information Technologies, 10(1-2), 111123.

UoW. (2006). University of Washington Certificate Program in Aircraft Composite Materials and Manufacturing. Retrieved January 19th, 20036

Van den Akker, J. J. H. (2003). Curriculum perspectives: an introduction. In J. van den Akker, W. Kuiper \& U. Hameyer (Eds.), Curriculum landscape and trends. Dordrecht: Kluwer Academic Publishers.

Winter, R. (1994). The problem of educational levels (part 2): a new framework for credit accumulation in higher education. Journal for Further and Higher Education, 18(1), 92-106.

XCRI. (2006). eXchanging Course-Related Information. Retrieved January 16th, 2006, from http://www.elframework.org/projects/xcri

Yorke, M. (1999). Leaving Early. Undergraduate Non-completion in Higher Education. London: Falmer Press. 
